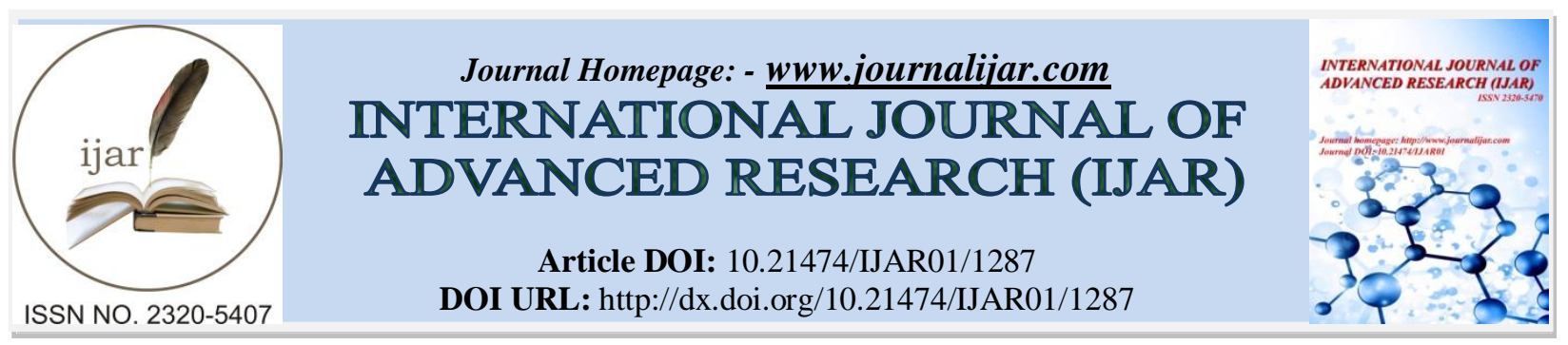

RESEARCH ARTICLE

\title{
EVALUATION OF FREE RADICAL SCAVENGING ACTIVITIES OF ACHYRANTHES ASPERA LINN. EXTRACT.
}

Vrushali Jadhav and S.D.Biradar.

Department Of Botany, Dnyanopasak Shikshan Mandal's, College Of Arts, Commerce and Science,Parbhani - 431 401 (M.S.)India.

\begin{tabular}{|c|c|}
\hline Manuscript Info & Abstract \\
\hline $\begin{array}{l}\text { Manuscript History } \\
\text { Received: } 12 \text { June } 2016 \\
\text { Final Accepted: } 19 \text { July } 2016 \\
\text { Published: August } 2016\end{array}$ & $\begin{array}{l}\text { Plants and plants products have been claimed to have health-promoting } \\
\text { effects, which may be related to the antioxidant activity in vitro. The } \\
\text { aim of this study was to determine antioxidant activity of selected plant } \\
\text { Achyranthes aspera Linn, in the present study, antioxidant activity of } \\
\text { methanol extract of A.aspera was examined by comparing it to the } \\
\text { activity of known antioxidants such as Ascorbic acid (Vit.C) along with } \\
\text { the measurement of their total phenol content. Results showed that the } \\
\text { inhibition DPPH radical was dependent on the concentration of the } \\
\text { extract. We found that these plant is a very good source of antioxidant } \\
\text { compounds. }\end{array}$ \\
\hline
\end{tabular}

Copy Right, IJAR, 2013,. All rights reserved.

\section{Introduction:-}

Modern life style imposes various detrimental impacts on the human population. Present day population relies on taking fast food because of their busy schedule. They are used to take pain killers for relief of pain, sedatives and alcohols to overcome the mental stress. All these result into oxidative stress According to Karbownik and Lewinski (2003), oxidative stress is involved in many diseases, such as atherosclerosis, Parkinson's disease, heart failure, myocardial infarction, Alzheimer's disease, and chronic fatigue syndrome. Oxidative stress depletes the antioxidants present in the body and become the causative factors for above mentioned physiological disorders (Paul et al., 2011). Therefore, there is a need to supplement the anti-oxidant system of our body. Best way to get rid of the imbalance is the supplementation of food with the diet rich in anti-oxidants. Green vegetables, leaves and fruits are the natural source of anti-oxidants. Apart from them, traditional medicines also play a significant role in alleviation of the oxidative stress conditions. Achyranthes aspera belongs to the family-Amaranthaceae. It is an annual, stiff erect herb, and found commonly as a weed throughout India and used by traditional healers for the treatment of fever, dysentery and diabetes (R. D. Girach.et al and Bkher et al ). The main objective of the present work was to evaluate of antioxidant potential of Achyranthes aspera selected by free radical scavenging activity (DPPH); in addition the total phenolic content in was also determined. The aim of this study was Achyranthes aspera also to refer the possibility use of biologically active components from these products in food industry.

Corresponding Author:- Vrushali Jadhav

Address:- Department Of Botany, Dnyanopasak Shikshan Mandal's, College Of Arts, Commerce and Science.Parbhani - 431401 (M.S.)India. 


\section{Materials:-}

Extraction of plant material:-

$10 \mathrm{~g}$ leaf powder of A. aspera were extracted with methanol using a Soxhlet apparatus for six to eight hours. Then extracts were filtered, evaporated and weights were taken. The dried extracts were dissolved in dimethyl sulphoxide (DMSO).

\section{Preparation of Standard:-}

Vit. C (Ascorbic acid) was used as a comparative standard.

\section{DPPH Photometric Assay:-}

The antioxidant activity of plant extract was determined using the 1, 1-diphenyl-2 picrylhydrazyl (DPPH) free radical scavenging assay. The free radical scavenging capacity of methanolic extract of plant material was determined using DPPH. The stock solution $(10 \mathrm{mg} / 100 \mathrm{ml})$ was prepared using DPPH solution $(0.004 \% \mathrm{w} / \mathrm{v})$ in $95 \%$ methanol. From the stock solution $2 \mathrm{ml}, 4 \mathrm{ml}, 6 \mathrm{ml}, 8 \mathrm{ml}$ and $10 \mathrm{ml}$ of this solution were taken in five test tubes and it is diluted with methanol to make a volume up to $10 \mathrm{ml}$, which having the concentration $20 \mu \mathrm{g} / \mathrm{ml}, 40 \mu \mathrm{g} / \mathrm{ml}$, $60 \mu \mathrm{g} / \mathrm{ml}, 80 \mu \mathrm{g} / \mathrm{ml}$ and $100 \mu \mathrm{g} / \mathrm{ml}$ respectively. Freshly prepared DPPH solution $(0.04 \%$ w/v) was added in each of these test tubes containing plant extract $(20 \mu \mathrm{g} / \mathrm{ml}, 40 \mu \mathrm{g} / \mathrm{ml}, 60 \mu \mathrm{g} / \mathrm{ml}, 80 \mu \mathrm{g} / \mathrm{ml}$ and $100 \mu \mathrm{g} / \mathrm{ml})$ and after 10 minutes the absorbance was taken at $517 \mathrm{~nm}$ using spectrophotometer. Ascorbic acid was used as a reference standard which is prepared by dissolving it in distilled water. The stock solution was prepared with the same concentration $(10 \mathrm{mg} / 100 \mathrm{ml}$ or $100 \mu \mathrm{g} / \mathrm{ml})$ of plant extract. Control sample was prepared using the same volume without any extract and reference ascorbic acid. The 95\% methanol was used as blank. The Percent scavenging of the DPPH free radical was measured using the following equation:

$\%$ DPPH radical scavenging $=($ Absorbance of control-Absorbance of test sample $) /($ Absorbance of control $) \times 100$ (Lee et al., 2003).

\section{Estimation of total phenolic content:-}

The assay used for the determination of total phenolics content employs Folin and Ciocalteu's phenol reagent which response depending on the chemical structure of phenolics (i.e. the higher the number of functional - $\mathrm{OH}$ group the higher the total phenolics content). Total soluble phenolic compounds in the ethanolic extracts were measured and expressed as gallic acid equivalents. A sample of the ethanolic extract was added to distilled water for a final volume of $2 \mathrm{ml}$. After, it was mixed with $0.3 \mathrm{ml}$ of a saturated sodium carbonate $\left(\mathrm{Na}_{2} \mathrm{CO}_{3}\right)$ solution and $0.1 \mathrm{ml}$ of 1 $\mathrm{N}$ Folin-Ciocalteu's phenol reagent. The mixture was placed for $1 \mathrm{~h}$ room temperature in the dark. The absorbance was measured at $725 \mathrm{~nm}$ against the blank. The total phenolic content was expressed as $\mathrm{mg}$ of gallic acid equivalent.

\section{Antioxidant activity of A. aspera:-}

The result of antioxidant activity of methanol extract of A.aspera was examined by comparing it to the activity of known antioxidants such as Ascorbic acid (Vit.C). The highest IC ${ }_{50}$ value of $80 \mu \mathrm{g} / \mathrm{ml}$ concentration was 76.32 while $34.83,46.85,47.97 \& 38.30$ values of $\mathrm{IC}_{50}$ had concentration range of $20,40,60,100 \mu \mathrm{g} / \mathrm{ml}$ (Table No.1).

Table No.1:- Antioxidant activity of A.aspera (Mean \pm S.D).

\begin{tabular}{|c|c|c|}
\hline \multirow{2}{*}{ Concentration $\boldsymbol{\mu g} / \mathbf{m l}$} & IC $_{\mathbf{5 0}}$ Values & Standard \\
\cline { 2 - 3 } & A.aspera methanolic extract & Ascorbic acid \\
\hline 20 & $34.83 \pm 0.89$ & $166.96 \pm 4.01$ \\
\hline 40 & $46.85 \pm 3.28$ & $137.83 \pm 1.69$ \\
\hline 60 & $47.97 \pm 0.78$ & $116.35 \pm 2.81$ \\
\hline 80 & $76.32 \pm 0.63$ & $114.65 \pm 1.44$ \\
\hline 100 & $38.30 \pm 0.06$ & $98.22 \pm 0.96$ \\
\hline
\end{tabular}

Total Polyphenol content:-

Since polyphenols significantly contribute to the overall antioxidant activity, which is expressed in $\mathrm{mg} / 100 \mathrm{~g}$ during present study A.aspera contributes maximum phenol content which is 406.33 


\section{Discussion:-}

The antioxidants protect from the potentially damaging oxidative stress, which is a result of an imbalance between the formation of ROS and the body antioxidant defense. Antioxidants have also been used in food industry to prevent deterioration, nutritional losses and off-flavoring in various foods, especially those containing polyunsaturated fatty acids. Recently, interest has increased considerably in finding naturally occurring antioxidants for use in foods because of their potential in health promotion and disease prevention, and their high safety and consumer acceptability Gorinstein et al., (2003). The results of DPPH free radical scavenging activities showed that the methanolic extracts of A.aspera used in this study were effective radical scavengers. DPPH radical scavenging assay of the methanolic extracts of the plant show a dose response pattern, which was comparably lower than that of the ascorbic acid .However, it was observed that the percentage DPPH scavenging activity of the methanolic extract was higher in A.aspera by comparing it to the activity of known antioxidants such as Ascorbic acid (Vit.C).80 $\mu \mathrm{g} / \mathrm{ml}$ concentration shows highest IC 50 values i.e. 76.32 while $34.83,46.85,47.97,98.30$ values of IC $_{50}$ has concentration range of $20,40,60,100 \mu \mathrm{g} / \mathrm{ml}$. Singh (2002) were studied that the antioxidant property of $A$. spinosus growing along roadside which is continuously exposed to the high levels of nitrogen oxides and sulphur dioxide through automobile emission which is correlated with present study. Edwin (2008) has also reported free radical scavenging property of the ethanolic and aqueous extracts of Achyranthes aspera the results of this study were agreed with present results.

\section{Conclusion:-}

In this study, we evaluated antioxidant activity of selected plant Part. Our results showed that tested plant had noticeably antioxidant effect and total phenolic content. Antioxidant compounds from these products with preventive and treatment effect on various diseases can be used for improving the shelf life of food products.

\section{References:-}

1. Bkher, Liersch R., Haensel, K., Keller, G., Rimpler, G., Schneider. (1992). (eds) Hagers Handbuch der Pharmazeutischen Praxis. V. Springer-Verlag, Berlin, 7, 54-59.

2. Edwin, S., Jarald, E., Edwin, D.L., Jain, A., Kinger, H., Dutt, K.R., and Raj, A.A. (2008). Isolation of Betain from Achyranthes aspera. Pharmaceutical Biology. 46 (12), 824-828.

3. Girach, R. D., Khan, A. S. A. (1992). Int J Pharmacogn, 30, 113-115.

4. Gorinstein, S., Yamamoto, K., Katrich, E., Leontowicz, H., Lojek, A., Leontowicz, M., Ciz,, M., Goshev I., Shalev, U and Trakhtenberg, S.(2003). Antioxidative properties of Jaffa sweeties and grapefruit and their influence on lipid metabolism and plasma antioxidative potential in rats,.Biosci Biotechnol Biochem. 67, 907910 .

5. Karbownik, M.I and Lewinski, A. (2003). The role of oxidative stress in physiological and pathological processes in the thyroid gland; possible involvement in pineal-thyroid interactions. Neuro Endocrinology Letters 24(5) 293-303.

6. Lee, S.E., Hwang, H.J. and Ha, J.S. (2003)., Screening Of Medicinal Plant Extracts For Antioxidant Activity. Life Science. 73,167-179.

7. Paul ,H.A., Hiroaki, K., and Ian, V.J.M. (2011). Oxidative Stress and Cell Membranes in the Pathogenesis of Alzheimer's Disease. Physiology 26(1) 54-69.

8. Singh, A.B and Dahiya, P., (2002). Antigenic and allergenic properties of Amaranthus spinosus pollen - a common growing weed in India. Ann Agric Environ Med. 9,147-151. 